\title{
ASSESSMENT OF ANTIOXIDANT EFFECTIVENESS ON THERMALLY TREATED MARINE LIPIDS BY FLUORESCENCE DETECTION
}

Santiago P. Aubourg

Instituto de Investigaciones Marinas (CSIC)

c/ E. Cabello, 6

36208-VIGO (Spain)

Fax: + 34-986-292762

E-mail: saubourg@iim.csic.es 


\begin{abstract}
Previous research has studied fluorescence development during fish processing; as a result, a bathochromic shift towards higher wavelength maxima was detected and employed successfully as a way of measuring quality changes. In the present work, the same fluorescence analysis was tested for assessing the preservative effect of an antioxidant compound on thermally treated marine lipids. For it, two kinds of marine lipids systems (cod liver oil and horse mackerel white muscle) were heated under different time (up to 15 days), temperature $\left(15^{\circ} \mathrm{C}, 30^{\circ} \mathrm{C}\right.$ and $50^{\circ} \mathrm{C}$ ) and antioxidant (citric acid) content $(0.01-0.50 \%$ in the oil systems, w/w; $0.10-1.00 \%$ in the fish muscle systems, w/w) conditions. Fluorescence results showed an antioxidant effect at all the temperatures studied; at $50^{\circ} \mathrm{C}$ the citric acid presence produced a significant decrease of the bathochromic shift of fluorescence in both the oil and the fish muscle systems when present in the following concentrations rangs: $0.10-0.50 \%$ and $0.40-1.00 \%$, respectively. The antioxidant effect of citric acid was also confirmed by the traditional browning development (420 nm) analysis. Good linear correlations were obtained for both fluorescence and browning values with the reaction time at all the temperatures tested. It is concluded that fluorescence analysis could be successfully employed as an accurate tool when studying the effect of antioxidant compounds during marine products manufacture, specially in cases where interaction compounds formation between lipid oxidation products and nucleophilic constituents are prone to be formed.
\end{abstract}

Running Title: Antioxidant effectiveness assessment by fluorescence detection Key Words: Marine lipids, antioxidant, heating, lipid oxidation, fluorescence 


\section{INTRODUCTION}

During processing and storage, enzymatic and nonenzymatic rancidity is known to play a very important role in the degradation processes that take place in fish $(1,2)$. The deterioration pathways have been explained on the basis of the high polyunsaturated fatty acids (PUFA) proportion found in marine species $(3,4)$ and the great diversity and content of different prooxidant molecules present in the fish muscle $(5,6)$.

To avoid lipid damage and extend the shelf life of fish products, a great attention is being given to the antioxidants employment $(7,8)$. Recent efforts are now focused in the replacement of synthetic antioxidants by natural ones. Reports have shown that synthetic antioxidants may act as mutagenic and carcinogenic agents $(9,10)$, while natural ones have been mentioned to provide nutritional and therapeutic effects (11). Thus, naturally occurring antioxidants have been successfully employed with marine oils $(12,13)$, minced fish $(14,15)$ and whole or filleted fish $(16,17)$.

Many methods have been used to measure primary (hydroperoxides) and secondary (carbonyl compounds) lipid oxidation products in foods, as a way of determining the degree of food damage $(18,19)$. However, most traditional lipid indices have found difficulties when measuring fish quality degradation during thermal treatments $(20,21)$. Recent research has shown that simultaneous fluorescence detection at different excitation/emission maxima could afford an accurate tool for assessment of lipid oxidation and quality changes during fish thermal treatment (22, 23).

In the present work, this fluorescence analysis is tested to follow the preservative effectiveness of an antioxidant compound on marine lipids (marine oil and fish muscle) during thermal treatment. Different time, temperature and antioxidant concentration conditions are studied. Lipid oxidation analysis is also carried out by measuring the 
browning development. As antioxidant compound, citric acid (CA) is employed as being one of the most common natural antioxidants utilised in biological systems and during fish processing $(8,24)$.

\section{MATERIALS AND METHODS}

Chemicals and raw fish material

All chemicals employed were reagent grade (E. Merck; Darmstadt, Germany).

Cod liver oil (CLO) was obtained from a commercial source (Bama Geve, S. A.; Barcelona, Spain). Before employing it, acid value (0.9 mg KOH/g lipids), peroxide value (1.6 meq $\mathrm{O}_{2} / \mathrm{kg}$ lipids) (25) and fatty acid composition (26) were analysed. The following proportions (\%) of fatty acids were obtained: 3.55 (C 14:0), 0.46 (C 15:0),

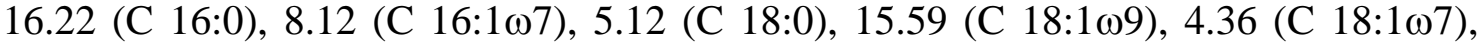

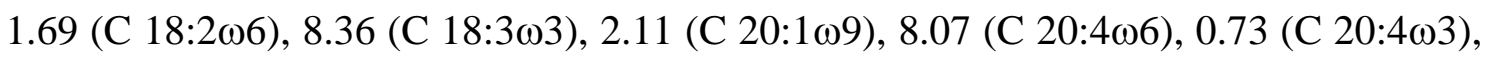
11.63 (C 20:5 22:6 $\omega 3)$.

Fresh horse mackerel (Trachurus trachurus) were obtained 10 h after catching; during this time the fish had been kept on ice. Upon arrival in our laboratory, the fish were employed in the present experiment.

Heated oil systems (OS)

CLO portions (0.5 g) were dissolved in choloroform $(10 \mathrm{ml})$. Ten $\mathrm{ml}$ of CA solutions prepared by dilution of a CA stock solution $(100 \mathrm{mg} / 100 \mathrm{ml}$ chloroform-aq. 86\% ethanol, 1:1) were added to obtain the following CA/CLO (w/w) proportions: 
0.00\% $\left(\mathrm{OS}_{0}\right), 0.01 \%\left(\mathrm{OS}_{1}\right), 0.02 \%\left(\mathrm{OS}_{2}\right), 0.05 \%\left(\mathrm{OS}_{3}\right), 0.10 \%\left(\mathrm{OS}_{4}\right), 0.20 \%\left(\mathrm{OS}_{5}\right)$ and 0.50\% $\left(\mathrm{OS}_{6}\right)$. Then, $10 \mathrm{ml}$ of a propylamine (Pam) solution $(1.4805 \mathrm{~g} / 500 \mathrm{ml}$ aq. $86 \%$ ethanol) were added. Reaction mixtures were incubated at $50^{\circ} \mathrm{C}$. Samples consisting of the $0.00 \%$ and $0.10 \%$ proportions $\left(\mathrm{OS}_{0}\right.$ and $\left.\mathrm{OS}_{4}\right)$ were also incubated at $15^{\circ} \mathrm{C}$ and $30^{\circ} \mathrm{C}$.

Reaction mixtures were incubated in all cases in triplicate in stoppered tubes in the dark without stirring and sampled at 1, 3, 6, 10 and 15 days for lipid oxidation assessment. Blank samples consisting of the individual starting reagents (CLO, Pam and CA) under the same reaction conditions were also checked.

Heated fish muscle systems (FMS)

Twelve individual fishes were divided into three batches. In each batch, the white muscle was manually separated out and then homogenised. Minced white muscle portions (5 g) of each batch were mechanically homogenised with $10 \mathrm{ml}$ of aq. $86 \%$ ethanol in $30 \mathrm{ml}$ stoppered tubes. Then, $5 \mathrm{ml}$ of CA solutions prepared by dilution of a CA stock solution (1.667 g/100 $\mathrm{ml}$ aq. $86 \%$ ethanol) were added to obtain the following CA/fish muscle (w/w) proportions: $0.10 \%\left(\mathrm{FMS}_{1}\right), 0.20 \%\left(\mathrm{FMS}_{2}\right), 0.40 \%\left(\mathrm{FMS}_{3}\right)$, 0.70\% $\left(\mathrm{FMS}_{4}\right)$ and $1.00 \%\left(\mathrm{FMS}_{5}\right)$. A fish muscle blank $\left(\mathrm{FMS}_{0}\right)$ was also studied.

Reaction mixtures were incubated in triplicate in the dark at $50^{\circ} \mathrm{C}$ without stirring and sampled at 1, 6 and 15 days for lipid oxidation assessment.

\section{Lipid oxidation assessment}

Fluorescence measurements (Perkin-Elmer LS 3B) were made at 327/415 nm and 393/463 nm excitation/emission maxima (20, 21). Relative fluorescences (RF) were calculated as $\mathrm{RF}=\mathrm{F} / \mathrm{F}_{\mathrm{st}}$, where $\mathrm{F}$ is the sample fluorescence at each excitation/emission maximum, and $\mathrm{F}_{\mathrm{st}}$ is the fluorescence intensity of a quinine sulphate 
solution ( $1 \mu \mathrm{g} / \mathrm{ml}$ in $\left.0.05 \mathrm{M} \mathrm{H}_{2} \mathrm{SO}_{4}\right)$ at the corresponding wavelength. The fluorescence ratio $(\delta \mathrm{F})$ value was calculated as: $\delta \mathrm{F}=\mathrm{RF}_{393 / 463 \mathrm{~nm}} / \mathrm{RF}_{327 / 415 \mathrm{~nm}}$.

Marine oil systems were analysed directly. Fish muscle systems were centrifuged (3000 x g for 10 minutes) and filtered. The resulting liquid part was exposed to UV light (350 nm) during $30 \mathrm{~s}$ to destroy any retinol present and was then analysed by fluorometry. Fluorescence was measured at room temperature $\left(16-18^{\circ} \mathrm{C}\right)$ with a 10 mm path-length quartz cuvette. Sensitive settings were: 5 (samples) and 0.5 (quinine sulphate standard solution).

Brown coloration was measured at $420 \mathrm{~nm}$ (27). Marine oil systems were analysed directly. Fish muscle systems were centrifuged (3000 x g for 10 minutes) and filtered. Browning was measured in the filtrate and results were calculated using the following formula (28): Browning value $=\mathrm{B} x \mathrm{~V} / \mathrm{w}$, where $\mathrm{B}$ is the absorbance reading at $420 \mathrm{~nm}, \mathrm{~V}$ denotes the volume $(\mathrm{ml})$ of the sample (30 $\mathrm{ml}$ for oil systems; $15 \mathrm{ml}$ for fish muscle systems) and $\mathrm{w}$ is the mass ( $\mathrm{g}$ ) of the sample ( $0.5 \mathrm{~g}$ for the oil systems; $5 \mathrm{~g}$ for fish muscle systems).

Statistical analysis

Fluorescence ratio $(\delta \mathrm{F})$ and browning values were subjected to the ANOVA one-way method $(\mathrm{p}<0.05)$; comparison of means after the ANOVA test were performed using a least-squares difference (LSD) method (29). Regression analyses were carried out according to Glantz and Slinker (30). 


\section{RESULTS AND DISCUSSION}

Samples corresponding to blanks of reacting molecules (Pam and CA) did not provide significant changes in the $\delta \mathrm{F}$ and browning values through the experimental conditions. Accordingly, the effect of CA on the lipid oxidation development is evaluated by comparison with the CLO blank and the CLO + Pam $\left(\mathrm{OS}_{0}\right)$ mixture in the case of the oil systems, and with the fish muscle blank $\left(\mathrm{FMS}_{0}\right)$ in the case of the fish muscle systems.

Heated marine oil systems

Although significant differences were not obtained among all the CA concentrations tested, a decreasing fluorescence development was assessed as higher CA contents were employed (Table 1). Comparison with the $\mathrm{OS}_{0}$ mixture lead to conclude a significant antioxidant effect of CA at the end of the experiment when present in the $0.02-0.50 \%$ concentration range. The CLO blank produced a slight $\delta \mathrm{F}$ value increase with the reaction time, but was lower than all the remaining reaction mixtures.

The assessment of the $\delta \mathrm{F}$ value showed a progressive increase of lipid oxidation with the reaction time for each CA/CLO reaction mixture as a result of the thermal conditions. These results can be explained by the fact that lipid oxidation compounds (peroxides, carbonyls and so on) interacted with propylamine to produce addition compounds with fluorescent properties (31-33).

Browning detection also provided an antioxidant effect of the CA presence by comparison of the different CA concentrations studied (Table 2). At the end of the reaction time, a significant effect could be observed for the $0.10-0.50 \%$ concentration 
range. Again, the CLO blank provided a slight increase with the reaction time, but was lower than the remaining reaction mixtures. As a result of the thermal treatment, increasing browning values with reaction time for each reaction mixture were obtained produced by a progressive formation of Schiff bases and other interaction compounds with increasing molecular weights and unsaturated bond numbers (34-36).

The effect of CA on the oxidative damage of heated CLO was studied at different temperatures $\left(15^{\circ} \mathrm{C}, 30^{\circ} \mathrm{C}\right.$ and $\left.50^{\circ} \mathrm{C}\right)$. The presence of CA led to significantly $(\mathrm{p}<0.05)$ lower $\delta \mathrm{F}$ values at the three temperatures tested (Figures 1 and 2$)$, so that an antioxidant effect could be concluded in all cases. Fluorescence detection showed large increasing values with the reaction time for both kinds of mixtures at $30^{\circ} \mathrm{C}$ and $50^{\circ} \mathrm{C}$; in the case of $15^{\circ} \mathrm{C}$, little significant increases were obtained with time.

The browning development also showed lower values when CA was applied (Table 3); significant differences were concluded at the end of the reaction time in the three temperatures tested. Increasing browning values were obtained as long as reaction time increased. This increase was especially sharp at $50^{\circ} \mathrm{C}$.

Correlations between the reaction time and both lipid damage indices at the different temperatures tested were studied (Table 4). Satisfactory linear correlations were obtained in all cases. According to the strong relationship between interaction compounds formation and temperature (34-36), correlations were better in the two highest temperatures $\left(30^{\circ} \mathrm{C}\right.$ and $\left.50^{\circ} \mathrm{C}\right)$ considered.

Heated fish muscle systems

Different CA contents were added to fish muscle to assess the antioxidant effect exerted on the muscle lipids during heat treatment. Comparison of the different mixtures 
at each reaction time showed a progressive decrease in the $\delta \mathrm{F}$ value as long as the CA proportion increased (Figure 3). At the end of the reaction time, comparison with the fish muscle blank $\left(\mathrm{FMS}_{0}\right)$ showed a significant antioxidant effect in the $0.40-1.00 \%$ concentration rang.

The fluorescence analysis showed a progressive increase with reaction time of lipid oxidation for the fish muscle blank $\left(\mathrm{FMS}_{0}\right)$. This increase could be explained as a result of interaction between the nucleophilic molecules from the fish muscle (proteins, peptides, free amino acids and phospholipids) and the lipid oxidation compounds formed during the thermal conditions (20, 23). Mixtures containing CA also showed an increase in lipid oxidation with the reaction time, according to the same interaction compounds formation $(20,23)$.

The browning analysis also showed an antioxidant effect of CA that was evident at the end of the reaction time in the $0.40-1.00 \%$ concentration rang (Table 5), as in the case of the $\delta \mathrm{F}$ value. As in the fluorescence analysis, increasing browning values were obtained with the reaction time for all kinds of mixtures, including the fish muscle blank $\left(\mathrm{FMS}_{\mathrm{o}}\right)$, that can be explained again by a progressive formation of addition compounds during the thermal treatment $(23,34,36)$. 


\section{CONCLUSIONS}

The $\delta \mathrm{F}$ value has been employed successfully as a way of assessing the preservative effect of an antioxidant compound on thermally treated marine lipids. A gradual decrease of the oxidation development was detected as a result of lowering the reaction time and temperature and by increasing the antioxidant content. Relationship between reaction time and interaction compounds formation was also evident by the $\delta \mathrm{F}$ value analysis. It is concluded that $\delta F$ value detection can afford a rapid, sensitive and valuable tool for assessing the antioxidant effect during food processes where lipid oxidation can have a strong effect on quality degradation. This would especially be the case of species supporting a high PUFA content (marine ones) when thermally treated.

\section{ACKNOWLEDGEMENTS}

The author acknowledges Mr. Luis Bar Fernández for technical assistance and the Xunta de Galicia for financial support through the research Project PGIDT 99 MAR 40202. 


\section{REFERENCES}

1. Hsieh R, Kinsella J (1989) Adv Food Res Nutr Res 33: 233-241

2. Hultin H (1992) Lipid oxidation in fish muscle. In Flick G, Martin R (eds) Advances in Seafood Biochemistry. Technomic Publishing Co, Inc, Lancaster-Basel, pp $99-122$

3. Pigott G, Tucker B (1987) Food Rev Intern 3: 105-138

4. Ackman R (1989) Fatty acids. In: Ackman R (ed) Marine biogenic lipids, fats and oils. CRC Press, Boca Raton, Florida (USA), Vol 1, pp 103-137

5. German B, Zhang H, Berger R (1992) Role of lipoxygenases in lipid oxidation in foods. In St. Angelo A (ed) Lipid oxidation in food. American Chemical Society, Washington, DC (USA), pp 74-92

6. Harris P, Tall J (1994) Rancidity in fish. In: Allen J, Hamilton R (eds) Rancidity in foods. Chapman and Hall, London (UK), pp 256-272

7. Erickson M (1997) Antioxidants and their application to frozen foods. In Erickson M, Hung Y-C (eds) Quality in frozen food. Chapman and Hall, New York (USA), pp 233-263

8. Decker E (1998) Trends Food Sci Technol 9: 241-248

9. Barlow S (1990) Toxicological aspects of antioxidants used as food additives. In Hudson B (ed) Food antioxidants. Elsevier, Amsterdam (Holland), pp 253-307

10. Ramanathan L, Das N (1993) J Food Sci 58: 318-320, 360

11. Frankel E (1995) Lipid Technol (July) 77-80

12. Ohshima T, Fujita Y, Koizumi C (1993) J Am Oil Chem Soc 70: 269-276

13. Hamilton R, Kalu C, McNeill G, Padley F, Pierce J (1998) J Am Oil Chem Soc 75: 813-822 
14. Kelleher S, Silva L, Hultin H, Wilhelm K (1992) J Food Sci 57: 1103-1108, 1119

15. Boyd L, Green D, Giesbrecht F, King M (1993) J Sci Food Agric 61: 87-93

16. Vareltzis K, Koufidis D, Graviilidou E, Papavergou E, Vasiliadou S (1997) Z Lebensm Unters Forsch 205: 93-96

17. Medina I, Sacchi R, Biondi L, Aubourg S, Paolillo L (1998) J Agric Food Chem 46: 1150-1157

18. Kim R, Labella F (1987) J Lipid Res 28: 1110-1117

19. Rossell J (1994) Measurement of rancidity. In Allen J, Hamilton R (eds) Rancidity in Foods. Blackie Academic and Professional, London (UK), pp 22-53

20. Aubourg S, Medina I, Pérez-Martín R (1995) Z Lebensm Unters Forsch 200: 252255

21. Aubourg S, Medina I (1997) J Agric Food Chem 45: 3617-3621

22. Aubourg S, Pérez-Martín R, Medina I, Gallardo J (1992) Z Lebensm Unters Forsch 195: 332-335

23. Aubourg S (1999) J Am Oil Chem Soc 76: 409-419

24. Maestro-Durán R, Borja-Padilla, R (1993) Grasas y Aceites 44: 208-212

25. Williams K (1950) Oils, fats and fatty foods. Their practical examination, $3^{\text {rd }}$ edn. J. \& A. Churchill Ltd, London (UK), pp 53-54, 107-108

26. Lepage G, Roy C (1986) J Lipid Res 27: 114-120

27. Labuza T, Massaro S (1990) J Food Sci 55: 821-826

28. Smith G, Hole M, Hanson S (1990) J Sci Food Agric 51: 193-205

29. Statsoft (1994) Statistica for Macintosh. Statsoft and its licensors. Tulsa, Oklahoma (USA)

30. Glantz S, Slinker B (1990) Primer of applied regression and analysis of variance. Mc Graw-Hill, New York (USA) 
31. Leake L, Karel M (1985) J Food Biochem 9: 117-136

32. Kikugawa K, Beppu M (1987) Chem Phys Lipids 44: 277-297

33. Montfoort A, Bezstarosti K, Groh M, Koster J (1987) FEBS Lett 226: 101-104

34. Cheftel J, Cheftel H (1976) Introducción a la Bioquímica y Tecnología de Alimentos. Acribia, Zaragoza (Spain), pp 291-308

35. Gardner H (1979) J Agric Food Chem 27: 220-229

36. Pokorný J (1981) Prog Food Nutr Sci 5: 421-428 
TABLE 1

Fluorescence ratio $(\delta \mathrm{F})$ values* obtained by heating cod liver oil $(\mathrm{CLO})$ at $50^{\circ} \mathrm{C}$ in the presence of propylamine (Pam) and citric acid (CA)**

TIME (days)

\begin{tabular}{|c|c|c|c|c|c|}
\hline $\begin{array}{l}\text { Reaction } \\
\text { Mixture }\end{array}$ & 1 & 3 & 6 & 10 & 15 \\
\hline CLO & $\begin{array}{l}2.71 \text { a } \\
(0.221)\end{array}$ & $\begin{array}{l}2.52 \text { a } \\
(0.255)\end{array}$ & $\begin{array}{l}3.01 \mathrm{a} \\
(0.531)\end{array}$ & $\begin{array}{l}3.50 \mathrm{a} \\
(0.110)\end{array}$ & $\begin{array}{l}4.09 \mathrm{a} \\
(1.198)\end{array}$ \\
\hline $\mathrm{OS}_{0}$ & $\begin{array}{l}10.53 \text { e } \\
(0.295)\end{array}$ & $\begin{array}{l}13.37 \mathrm{f} \\
(0.549)\end{array}$ & $\begin{array}{l}14.80 \mathrm{f} \\
(0.376)\end{array}$ & $\begin{array}{l}19.46 \mathrm{f} \\
(1.150)\end{array}$ & $\begin{array}{c}24.46 \mathrm{e} \\
(1.470)\end{array}$ \\
\hline $\mathrm{OS}_{1}$ & $\begin{array}{l}8.38 \mathrm{~d} \\
(0.822)\end{array}$ & $\begin{array}{l}11.86 \text { e } \\
(0.894)\end{array}$ & $\begin{array}{l}15.47 \mathrm{f} \\
(0.305)\end{array}$ & $\begin{array}{c}19.18 \text { ef } \\
(0.458)\end{array}$ & $\begin{array}{c}22.60 \mathrm{e} \\
(1.357)\end{array}$ \\
\hline $\mathrm{OS}_{2}$ & $\begin{array}{c}8.01 \mathrm{~cd} \\
(0.853)\end{array}$ & $\begin{array}{c}11.40 \text { de } \\
(1.268)\end{array}$ & $\begin{array}{l}14.77 \mathrm{f} \\
(0.690)\end{array}$ & $\begin{array}{c}17.99 \text { de } \\
(0.294)\end{array}$ & $\begin{array}{c}20.13 \mathrm{~d} \\
(0.866)\end{array}$ \\
\hline $\mathrm{OS}_{3}$ & $\begin{array}{c}7.39 \text { bc } \\
(0.064)\end{array}$ & $\begin{array}{c}10.40 \mathrm{~cd} \\
(0.028)\end{array}$ & $\begin{array}{l}13.41 \mathrm{e} \\
(0.764)\end{array}$ & $\begin{array}{l}17.52 \mathrm{~d} \\
(1.768)\end{array}$ & $\begin{array}{c}19.72 \mathrm{~cd} \\
(1.867)\end{array}$ \\
\hline $\mathrm{OS}_{4}$ & $\begin{array}{l}6.82 \mathrm{~b} \\
(0.173)\end{array}$ & $\begin{array}{l}9.27 \text { bc } \\
(0.152)\end{array}$ & $\begin{array}{l}11.77 \mathrm{~d} \\
(0.111)\end{array}$ & $\begin{array}{l}15.93 \text { с } \\
(0.285)\end{array}$ & $\begin{array}{c}18.43 \mathrm{~cd} \\
(0.752)\end{array}$ \\
\hline $\mathrm{OS}_{5}$ & $\begin{array}{l}6.67 \mathrm{~b} \\
(0.075)\end{array}$ & $\begin{array}{l}8.56 \mathrm{~b} \\
(0.046)\end{array}$ & $\begin{array}{l}10.82 \text { c } \\
(0.082)\end{array}$ & $\begin{array}{l}15.33 \text { с } \\
(0.837)\end{array}$ & $\begin{array}{l}17.84 \text { c } \\
(1.180)\end{array}$ \\
\hline $\mathrm{OS}_{6}$ & $\begin{array}{l}6.55 \mathrm{~b} \\
(0.448)\end{array}$ & $\begin{array}{l}8.24 \text { b } \\
(0.199)\end{array}$ & $\begin{array}{l}10.01 \mathrm{~b} \\
(0.189)\end{array}$ & $\begin{array}{l}13.65 \mathrm{~b} \\
(0.453)\end{array}$ & $\begin{array}{c}15.66 \mathrm{~b} \\
(0.674)\end{array}$ \\
\hline
\end{tabular}

* Mean values of three independent determinations. Values in the same column followed by different letters are significantly different $(p<0.05)$. Standard deviations are indicated in parentheses. Initial $\delta \mathrm{F}$ value of CLO was $2.68 \pm 0.062$.

** Different CA/CLO ratios (w/w) in the presence of Pam were checked: $\mathrm{OS}_{0}(0.00 \%)$, $\mathrm{OS}_{1}(0.01 \%), \mathrm{OS}_{2}(0.02 \%), \mathrm{OS}_{3}(0.05 \%), \mathrm{OS}_{4}(0.10 \%), \mathrm{OS}_{5}(0.20 \%)$ and $\mathrm{OS}_{6}$ (0.50\%). 


\section{TABLE 2}

Browning values* obtained by heating cod liver oil (CLO) at $50^{\circ} \mathrm{C}$ in the presence of propylamine and citric acid (CA)**

TIME (days)

\begin{tabular}{|c|c|c|c|c|c|}
\hline $\begin{array}{l}\text { Reaction } \\
\text { Mixture }\end{array}$ & 1 & 3 & 6 & 10 & 15 \\
\hline CLO & $\begin{array}{l}1.24 \mathrm{a} \\
(0.362)\end{array}$ & $\begin{array}{l}2.00 \mathrm{a} \\
(0.296)\end{array}$ & $\begin{array}{c}2.76 \mathrm{a} \\
(0.208)\end{array}$ & $\begin{array}{l}2.86 \mathrm{a} \\
(0.035)\end{array}$ & $\begin{array}{c}3.34 \mathrm{a} \\
(0.544)\end{array}$ \\
\hline $\mathrm{OS}_{0}$ & $\begin{array}{l}3.26 \mathrm{~d} \\
(0.400)\end{array}$ & $\begin{array}{l}5.02 \text { с } \\
(0.183)\end{array}$ & $\begin{array}{l}6.62 \mathrm{~cd} \\
(0.828)\end{array}$ & $\begin{array}{l}7.83 \mathrm{~cd} \\
(0.552)\end{array}$ & $\begin{array}{l}9.90 \text { e } \\
(0.433)\end{array}$ \\
\hline $\mathrm{OS}_{1}$ & $\begin{array}{c}2.72 \mathrm{~cd} \\
(0.227)\end{array}$ & $\begin{array}{l}5.26 \text { c } \\
(0.367)\end{array}$ & $\begin{array}{l}7.41 \mathrm{~d} \\
(0.127)\end{array}$ & $\begin{array}{l}8.54 \text { de } \\
(0.069)\end{array}$ & $\begin{array}{c}9.82 \text { de } \\
(0.193)\end{array}$ \\
\hline $\mathrm{OS}_{2}$ & $\begin{array}{l}2.46 \text { bc } \\
(0.000)\end{array}$ & $\begin{array}{c}4.88 \mathrm{c} \\
(0.503)\end{array}$ & $\begin{array}{l}7.24 \mathrm{~d} \\
(0.589)\end{array}$ & $\begin{array}{l}8.76 \text { e } \\
(0.068)\end{array}$ & $\begin{array}{c}9.48 \text { de } \\
(0.785)\end{array}$ \\
\hline $\mathrm{OS}_{3}$ & $\begin{array}{c}2.76 \mathrm{~cd} \\
(0.908)\end{array}$ & $\begin{array}{l}3.99 \text { b } \\
(0.127)\end{array}$ & $\begin{array}{l}7.23 \mathrm{~d} \\
(0.042)\end{array}$ & $\begin{array}{l}8.34 \text { de } \\
(0.424)\end{array}$ & $\begin{array}{c}9.09 \text { cde } \\
(0.382)\end{array}$ \\
\hline $\mathrm{OS}_{4}$ & $\begin{array}{l}2.18 \text { bc } \\
(0.386)\end{array}$ & $\begin{array}{l}3.70 \text { b } \\
(0.139)\end{array}$ & $\begin{array}{l}6.10 \text { bc } \\
(0.604)\end{array}$ & $\begin{array}{l}7.48 \text { c } \\
(0.341)\end{array}$ & $\begin{array}{c}8.98 \mathrm{~cd} \\
(0.426)\end{array}$ \\
\hline $\mathrm{OS}_{5}$ & $\begin{array}{l}2.00 \mathrm{~b} \\
(0.092)\end{array}$ & $\begin{array}{l}3.50 \mathrm{~b} \\
(0.092)\end{array}$ & $\begin{array}{l}5.44 \mathrm{~b} \\
(0.330)\end{array}$ & $\begin{array}{l}7.32 \text { c } \\
(0.375)\end{array}$ & $\begin{array}{l}8.52 \text { c } \\
(0.469)\end{array}$ \\
\hline $\mathrm{OS}_{6}$ & $\begin{array}{l}2.40 \text { bc } \\
(0.104)\end{array}$ & $\begin{array}{l}3.48 \mathrm{~b} \\
(0.216)\end{array}$ & $\begin{array}{l}5.42 \text { b } \\
(0.227)\end{array}$ & $\begin{array}{l}6.56 \mathrm{~b} \\
(0.330)\end{array}$ & $\begin{array}{l}7.58 \text { b } \\
(0.661)\end{array}$ \\
\hline
\end{tabular}

* Mean values of three independent determinations. Values in the same column followed by different letters are significantly different $(\mathrm{p}<0.05)$. Standard deviations are indicated in parentheses. Initial browning value of CLO was $1.28 \pm 0.433$.

** The same CA/CLO ratios (w/w) mentioned in Table 1 were employed. 
TABLE 3

Browning values* obtained by heating cod liver oil (CLO) at different temperatures in the presence of propylamine and citric acid at different temperatures**

\section{TEMPERATURE}

\begin{tabular}{|c|c|c|c|c|}
\hline $\begin{array}{l}\text { Reaction } \\
\text { Mixture }\end{array}$ & Time (days) & $15^{\circ} \mathrm{C}$ & $30^{\circ} \mathrm{C}$ & $50^{\circ} \mathrm{C}$ \\
\hline $\mathrm{OS}_{0}$ & 1 & $\begin{array}{c}1.68 \mathrm{a} \\
(0.240)\end{array}$ & $\begin{array}{l}2.36 \text { a } \\
(0.557)\end{array}$ & $\begin{array}{l}3.26 \mathrm{~b} \\
(0.400)\end{array}$ \\
\hline “ & 3 & $\begin{array}{c}2.14 \mathrm{a} \\
(0.193)\end{array}$ & $\begin{array}{l}3.14 \mathrm{~b} \\
(0.035)\end{array}$ & $\begin{array}{l}5.02 \mathrm{c} \\
(0.183)\end{array}$ \\
\hline “ & 6 & $\begin{array}{l}3.20 \mathrm{a} \\
(0.151)\end{array}$ & $\begin{array}{l}4.58 \mathrm{~b} \\
(0.284)\end{array}$ & $\begin{array}{l}6.62 \mathrm{c} \\
(0.828)\end{array}$ \\
\hline “ & 10 & $\begin{array}{c}3.72 \text { a } \\
(0.749)\end{array}$ & $\begin{array}{l}5.10 \text { b } \\
(0.216)\end{array}$ & $\begin{array}{l}7.83 \mathrm{c} \\
(0.552)\end{array}$ \\
\hline “ & 15 & $\begin{array}{l}4.10 \mathrm{a} \\
(0.500)\end{array}$ & $\begin{array}{l}5.78 \text { b } \\
(0.173)\end{array}$ & $\begin{array}{l}9.90 \mathrm{c} \\
(0.433)\end{array}$ \\
\hline $\mathrm{OS}_{4}$ & 1 & $\begin{array}{c}1.20 \mathrm{a} \\
(0.159)\end{array}$ & $\begin{array}{l}2.26 \mathrm{~b} \\
(0.092)\end{array}$ & $\begin{array}{l}2.18 \mathrm{~b} \\
(0.386)\end{array}$ \\
\hline “ & 3 & $\begin{array}{c}1.62 \mathrm{a} \\
(0.360)\end{array}$ & $\begin{array}{l}2.66 \mathrm{~b} \\
(0.035)\end{array}$ & $\begin{array}{l}3.70 \mathrm{c} \\
(0.139)\end{array}$ \\
\hline “ & 6 & $\begin{array}{l}2.60 \mathrm{a} \\
(0.613)\end{array}$ & $\begin{array}{l}3.36 \text { a } \\
(0.375)\end{array}$ & $\begin{array}{l}6.10 \mathrm{~b} \\
(0.604)\end{array}$ \\
\hline “ & 10 & $\begin{array}{l}2.86 \mathrm{a} \\
(0.538)\end{array}$ & $\begin{array}{l}3.84 \mathrm{~b} \\
(0.480)\end{array}$ & $\begin{array}{l}7.48 \mathrm{c} \\
(0.341)\end{array}$ \\
\hline “ & 15 & $\begin{array}{c}3.26 \text { a } \\
(0.828)\end{array}$ & $\begin{array}{l}4.26 \text { a } \\
(0.317)\end{array}$ & $\begin{array}{l}8.98 \mathrm{~b} \\
(0.426)\end{array}$ \\
\hline
\end{tabular}

* Mean values of three independent determinations. Values in the same raw followed by different letters are significantly different $(\mathrm{p}<0.05)$. Standard deviations are indicated in parentheses. Initial browning value of CLO was $1.28 \pm 0.433$.

** Abbreviations $\left(\mathrm{OS}_{0}\right.$ and $\left.\mathrm{OS}_{4}\right)$ as specified in Table 1. 
TABLE 4

Linear correlation coefficients* between the reaction time and both lipid oxidation values (fluorescence ratio, $\delta \mathrm{F}$; browning, $\mathrm{B}$ ) at different temperatures $* *$

\section{TEMPERATURE}

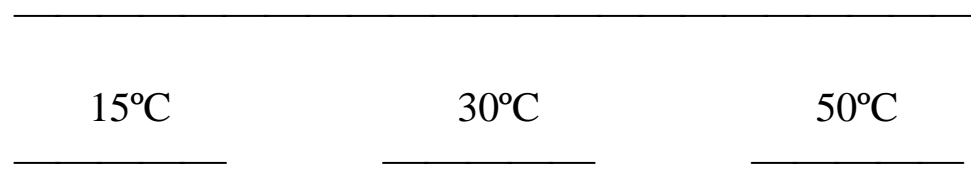

Reaction Mixture

$\begin{array}{ccccccc} & \delta \mathrm{F} & \mathrm{B} & \delta \mathrm{F} & \mathrm{B} & \delta \mathrm{F} & \mathrm{B} \\ \mathrm{OS}_{0} & 0.83 & 0.89 & 0.93 & 0.94 & 0.98 & 0.95 \\ \mathrm{OS}_{4} & 0.76 & 0.82 & 0.93 & 0.92 & 0.99 & 0.97\end{array}$

* Significant values $(\mathrm{p}<0.05)$ were obtained in all cases.

** Abbreviations ( $\left(\mathrm{OS}_{0}\right.$ and $\left.\mathrm{OS}_{4}\right)$ as specified in Table 1. 
Browning values* obtained by heating horse mackerel white muscle at $50^{\circ} \mathrm{C}$ in the presence of citric acid (CA)**

\begin{tabular}{lccc} 
& \multicolumn{3}{c}{ TIME (days) } \\
\cline { 2 - 4 } $\begin{array}{l}\text { Reaction } \\
\text { Mixture }\end{array}$ & 1 & 6 & 15 \\
& & & \\
FMS $_{0}$ & & & $0.41 \mathrm{c}$ \\
& & & $(0.015)$ \\
FMS $_{1}$ & $(0.026)$ & $(0.006)$ & $0.34 \mathrm{c}$ \\
& & & $(0.040)$ \\
$\mathrm{FMS}_{2}$ & $0.20 \mathrm{a}$ & $0.31 \mathrm{c}$ & \\
& $(0.035)$ & $(0.025)$ & $0.37 \mathrm{bc}$ \\
$\mathrm{FMS}_{3}$ & $0.18 \mathrm{a}$ & $0.30 \mathrm{bc}$ & $(0.015)$ \\
& $(0.025)$ & $(0.021)$ & $0.36 \mathrm{ab}$ \\
$\mathrm{FMS}_{4}$ & $0.19 \mathrm{a}$ & $0.28 \mathrm{bc}$ & $(0.042)$ \\
& $(0.021)$ & $(0.065)$ & $0.33 \mathrm{ab}$ \\
$\mathrm{FMS}_{5}$ & $0.20 \mathrm{a}$ & $0.24 \mathrm{ab}$ & $(0.035)$ \\
& $(0.035)$ & $(0.030)$ & $0.31 \mathrm{a}$ \\
& $0.18 \mathrm{a}$ & $0.21 \mathrm{a}$ & $(0.020)$
\end{tabular}

* Mean values of three independent determinations. Values in the same column followed by different letters are significantly different $(\mathrm{p}<0.05)$. Standard deviations are indicated in parentheses. Initial browning value of the fish muscle: $0.19 \pm 0.016$.

** Different CA/fish muscle ratios (w/w) were checked: $\mathrm{FMS}_{0}(0.00 \%), \mathrm{FMS}_{1}(0.10 \%)$, $\mathrm{FMS}_{2}(0.20 \%), \mathrm{FMS}_{3}(0.40 \%), \mathrm{FMS}_{4}(0.70 \%)$ and $\mathrm{FMS}_{5}(1.00 \%)$. 


\section{FIGURE LEGENDS}

FIGURE 1: Fluorescence ratio $(\delta \mathrm{F})$ values* obtained by heating cod liver oil at $15^{\circ} \mathrm{C}$, $30^{\circ} \mathrm{C}$ and $50^{\circ} \mathrm{C}$ in the presence of propylamine.

* Initial $\delta$ F value of the oil: $2.68 \pm 0.062$.

FIGURE 2: Fluorescence ratio $(\delta \mathrm{F})$ values* obtained by heating cod liver oil (CLO) at $15^{\circ} \mathrm{C}, 30^{\circ} \mathrm{C}$ and $50^{\circ} \mathrm{C}$ in the presence of propylamine and citric acid (CA)**.

* Initial $\delta \mathrm{F}$ value of the oil: $2.68 \pm 0.062$.

** A $0.10 \%$ CA/CLO ratio (w/w) was employed.

FIGURE 3: Fluorescence ratio $(\delta F)$ values* obtained by heating horse mackerel white muscle at $50^{\circ} \mathrm{C}$ in the presence citric acid (CA)**.

* Initial $\delta \mathrm{F}$ value of the fish muscle: $0.82 \pm 0.090$.

** Different CA/fish muscle (w/w) proportions were studied: $\mathrm{FMS}_{0}(0.00 \%), \mathrm{FMS}_{1}$ (0.10\%), $\mathrm{FMS}_{2}(0.20 \%), \mathrm{FMS}_{3}(0.40 \%), \mathrm{FMS}_{4}(0.70 \%)$ and $\mathrm{FMS}_{5}(1.00 \%)$. 